\title{
Jember Fashion Carnaval: Tourism Catalyst of East Java
}

\author{
Jajang Gunawijaya \\ Faculty of Social and Political Science, Universitas Indonesia \\ *Email: j_gunawijaya@yahoo.com
}

\begin{abstract}
Jember Fashion Carnaval (JFC) is a cultural event created by a prominent fashion designer in Jember City. The existence of these events has transformed the City of Jember, which was just a little-known small town, into a city that is widely known nationally and internationally. Events on stage and the most colossal fashion show with the longest and largest catwalk in the world, using the road segments protocol in the City of Jember are witnessed by thousands of tourists. Research using observation methods, FGD and in-depth interviews with JFC actors revealed that the event involves an invention of tradition, which takes place every year, and becomes a catalyst for the development of Jember city tourism which inflates the number of tourist visits to other tourist attraction locations in the city. JFC is a city icon that has an economic multiplier effect for the City of Jember.
\end{abstract}

Keywords: JFC, cultural events, tours, traditional invention, icons

\section{Introduction}

Jember is a district of East Java Province. It is adjacent to Bondowoso and Probolinggo regencies in the north; Lumajang regency in the west, Banyuwangi regency in the east, and in the south it extends as far as the Indonesian Ocean. These districts are in the area of East Java Province, The total area of Jember Regency is about $3,293.34 \mathrm{~km}^{2}$ with tofografi in the north and south coast, at an altitude of 0 to 3,330 masl. This condition means that the tropical climate in Jember Regency has a temperature of between 23 and 32 degrees Celsius (Jember District Statistics 2016). The population of Jember Regency in 2015 reached 2,345,851 inhabitants, with a population density of about 712 inhabitants $/ \mathrm{km}^{2}$ (https://jemberkab.go.id).

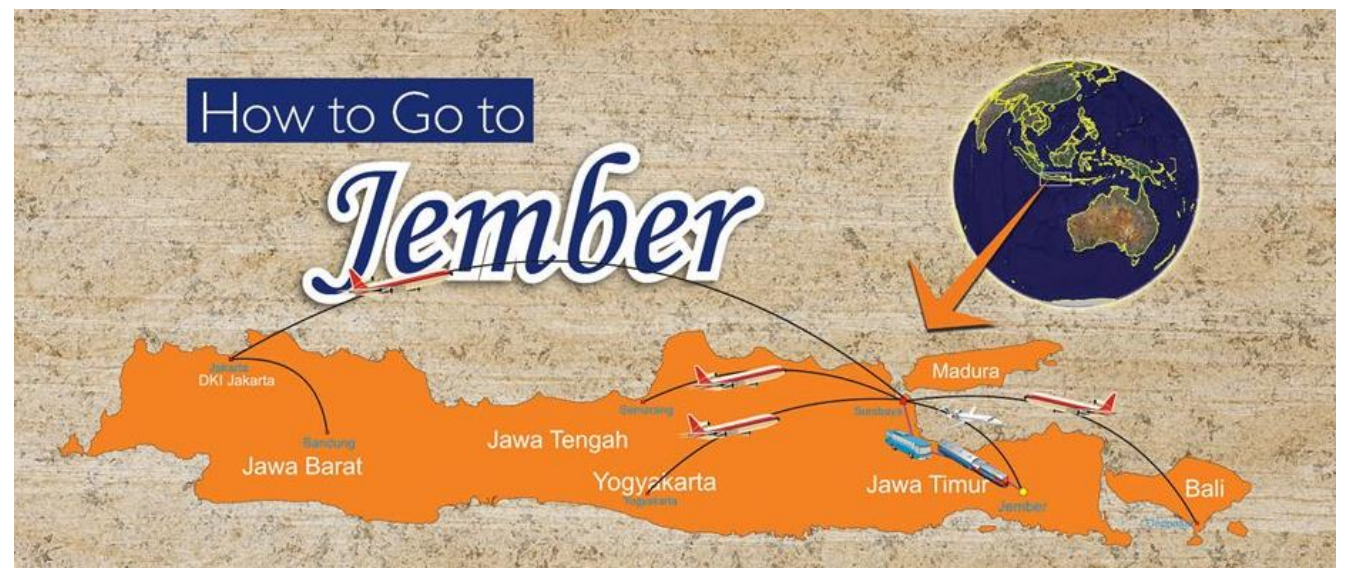

Fig. 1 How to visit Jember.

The main economic activities in the district are agriculture/plantations, trade, processing industry, construction, transportation, and the services sector. In the plantation industry the region is known as a producer of tobacco, coffee, and chocolate commodities whose production is directed for domestic use as well as the export market.

Ethnically the population of the region is a mixture of migrants from the surrounding areas, especially from Madurese and East Java ethnic groups who have interacted with each other over a relatively long period of time, so both have experienced the process of acculturation, and assimilation. The result of the acculturation and assimilation process gave birth to a new culture or tradition, which is known as the culture of shelter (pendhalun- 
gan). The mixed culture eventually became the icon of the Jember Carnival Festival (JFC) a gigantic annual cultural event that became the pride of Jember and Central Java people.

JFC was created by Dynand Fariz, a designer from Jember, through the foundation of the Jember Fashion Carnaval Council (JFCC). The event was first held in 2013 as a test event. After the success of the inaugural event, the creator tried to repeat it the following year. It turned out that, in the second implementation, it became more successful, so it has continued to be held intermittently in the following years, finally becoming an annual event always held in the City of Jember. Dynand Fariz as the creator of this huge event continues to develop JFC to become an international event.

\subsection{Research Problems}

The JFC, which was first held in 2013 by a local foundation, continues to run annually in Jember, East Java, and has received a positive response not only from the local people but also from the wider international community, spreading its fame. Based on this, the questions of my research are: (1) Why is JFC acceptable to local people and widespread? (2) What is the function of the existence of such events for the existence of Jember; (3) How do JFC's activities take place and what are the impacts for the local tourism industry; (4) and what is the JFC's effect on local communities on local economy, culture and creativity?

\subsection{Conceptual Base}

According to Hobsbawm (1992) the invention of tradition is a reasonable set of practices, in accordance with the rules or norms generally accepted, through the establishment, and planting of values, norms in certain behaviors that take place through repetition-repetitions related to past history. The invention of tradition is a process of formalization and ritualization whose characteristics refer to the past and enacted repetitively (repetition). This process takes place continuously and is growing widely. The invention of tradition also responds to new situations, although brought from the old situation, referenced through the process of repetition (Hobsbawm, 1992).

A number of local figures in Indonesia are able to create new cultural events with widespread influence and various circles of society can prosper from this. Gunawijaya (2011) examines the invention of traditions that occurred in Mount Halimun, Tingga Plateau Outback Sukabumi District, West Java, and were created by Abah Anom as the instigator of Kasepuhan customs. The invention of these traditions is a cultural event in the form of Sundanese arts performances in the Four Teens event, which takes place every month; a series of traditional ceremonies routinely held every year that is the Seren Taun ceremony; a series of marriage ceremonies and the creation of a new art form. In the Four Teens night event (Opat Belasan night) were displayed various forms of traditional Sundanese arts ranging from golek puppets, jipeng (tanji and mask), mask performance, and jaipongan dance simultaneously in the Court of Big House or the Square of the Elders. The event was not there and was only held in 2000 on the initiative of AbahEncup of the late Abah Anom, and continues to the present day. At the Opat Belasan night event, people can choose their favorite shows freely, chatting, and dating. Every month the village in the wilderness, located in the mountains with an altitude of 1200 to $1500 \mathrm{~m}$ above sea level, becomes lively with noisy frenetic voice (tetabuhan) and crowds until late into the night. Because it continues continuously, it becomes a process of formalization, and ritualization that is followed by all Kasepuhan residents, to become a new custom that binds the people of Kasepuhan Mount Halimun together.

Mustofa (2015) encompasses the creation of local creativity with traditional invention at the Angklung Mang Ujo studio in Bandung. The angklungs studio never existed, until, in the early 1970s, Ujo Nalagenaor MangUjo, with his creativity and personality strength, created the angklung studio into a tradition-based art performance that shot from local traditions to the wider world. With the studio, he not only changed the angklung from a Sundanese traditional instrument that was unpopular, to become a musical instrument that is well thought of nationally, and also makes the studio became a national and international tourist destination that can support the artistic community itself and spread benefits to the wider Bandung community.

The phenomenon of inventing traditions such as those that took place in Jember have long been seen in other countries, as proposed by Cannadine (1992), who examines the ceremonial significance of the British Empire, in the context of the history of the past and its development until the latter half of the 20th century. TrevorRoper (1992) examined the traditional Scottish highland dress (tartan) that was once considered bizarre, "plebeian," less civilized and so forth, transformed into a prestige practice. Anthropologists such as Sylvia Rodriguez (1997) studied the Taos party in Mexico, which became a party of pride for the Spanish-American Indians in Mexico. Robert Cancel (2006) reviews the Mutomboko Festival in Africa driven by traditional Lunda leaders within the sovereignty of the Republic of Zambia; Terence Ranger (1992) writes about various European tradi- 
tions in the colonies of European countries on the continent of Africa, which became a status symbol for the white people living in the colonies.

The studies of tradition are not studies of long-standing or ancient traditions, but are studies of new traditions that are driven or organized by a group of initiators for specific purposes. The process of forming a new tradition is clear and resolute that is, the old tradition or the product of the old tradition by a group of initiators renewed, or made new creations, wrapping them with old symbols until accepted by the people and practiced in everyday life.

\subsection{The Research Method}

The data that became the material of this writing, obtained from a short field research visit in the City of Jember, focuses on the importance of the JFC event in boosting tourism activities in the city and surrounding areas. Our main method is to conduct FGD with stakeholders in Jember, which is filled from the official of Tourism Office of Regency/City of Jember by as many as five people; three Jember government officials; three local artists and three cultural journalists. We also conducted a special interview with one of the leaders of the Carnival Fashion Council (JFCC), who was an organizer and responsible for the JFC, and we also observed the location and workshop of the JFC in their school.

To know the impact of JFC on other tourist attractions, the authors make observations and conduct interviews with the traditional tourist destinations in between the agro-tourism coffee plantations and cigar processing factory that is Boss Image Nusantara (BIN). It was at this location that we conducted special interviews with top management. Observations were also conducted at the P.T. Perkebunan Nusantara Coffee Division and a cigar manufacturer called BIN. The observation was carried out to see the tourism facilities provided by the agro-tourism manager, the intensity, and activity of tourists in the agro-tourism destination in the period around JFC events and before and after the JFC itself.

\subsection{JFC 4E Concept}

JFC was originally an initiative of a designer from Jember named Dynand Fariz. Through a foundation named the JFCC, Dynand Fariz then developed JFC into its present form. Ideas about JFC are fostered to fulfill what they call the 4Es, namely Education, Entertainment, Exhibition, and Economic benefits (http://www.jemberfashioncarnaval.com.).

\section{Discussion}

\section{Jember Fashion Carnaval (JFC) as a Tourism Catalyst}

JFC is an annual event held in Jember and has become the carnival event with the longest catwalk in Indonesia and even the world, reaching $3.6 \mathrm{~km}$. In this event are displayed the works of participants manifested in unique and magnificent costumes. The JFC series of events lasts for several days (in the past few years packed into four days) with its peak activity a unique and complete costume parade along with its attributes on the last day.

Each year, JFC has a different theme. Themes are tailored to the development of world fashion and trends. This is because JFC is an international class event that is aimed at a global audience Furthermore, the parade is grouped into several lines (generally 8-10 groups) each containing a maximum of 40 participants. Based on the big theme, the lines are then formed to produce thematic costumes. Technically, it is useful to facilitate the parade and ensure participants contribute the most to the carnival. In each event, participants will compete with each other to obtain the best result from JFC. In total, by 2016 there are about 80 types of award categories to the participants. Grand carnival events will be scrutinized through strict judging by the committee before deciding the winner. 


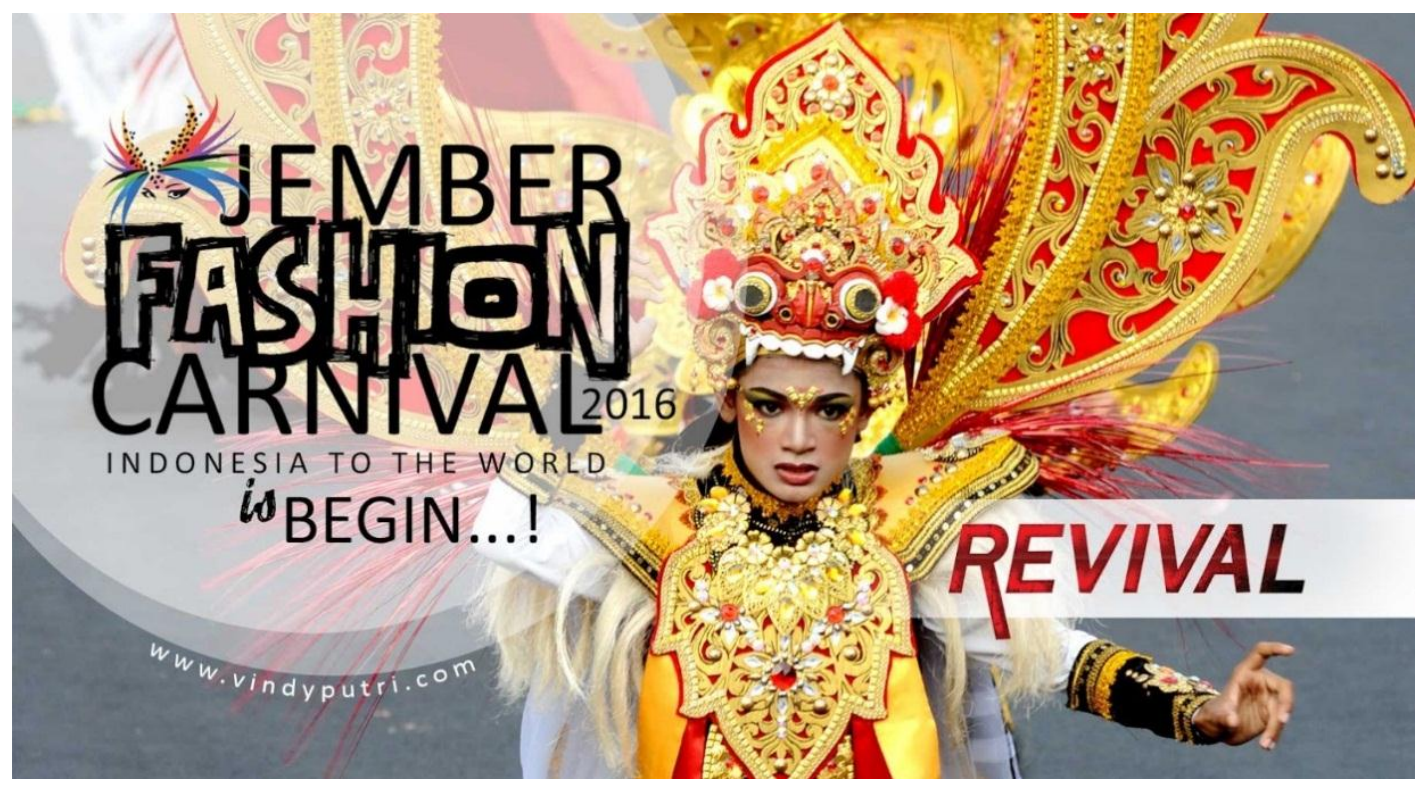

Fig. 2 "Revival" selected as JFC 2016 theme.

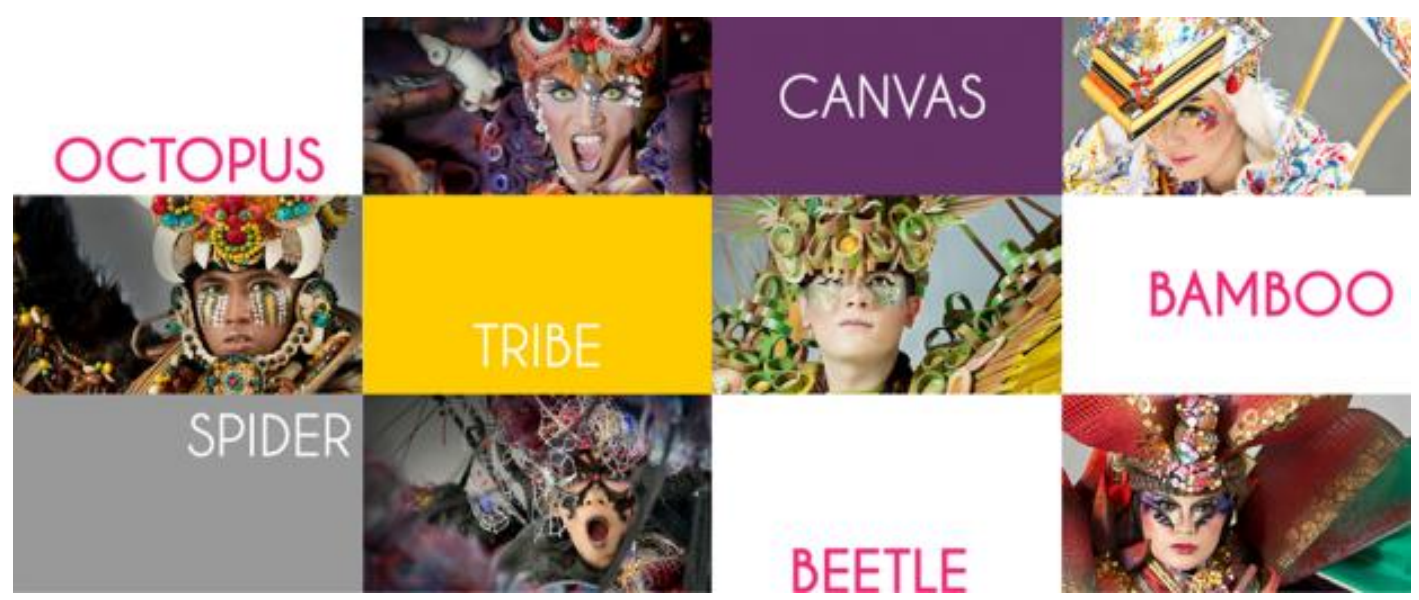

Fig. 3 Themes in JFC to 12 of 2013

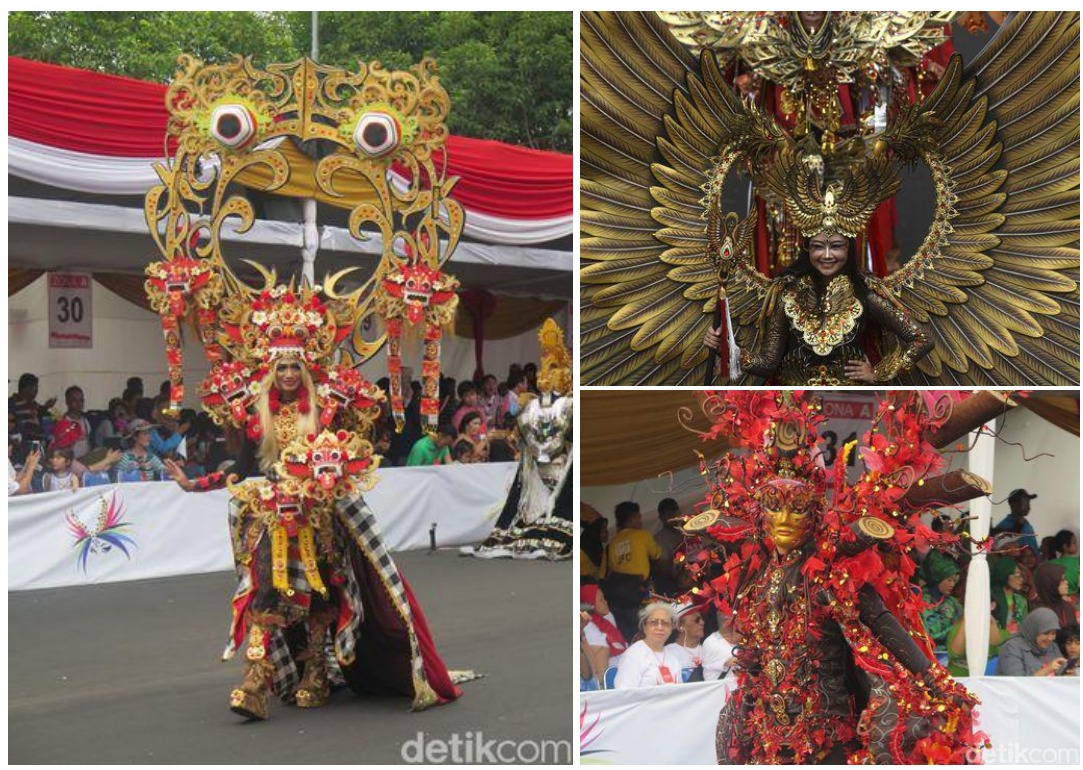

Fig. 4 Some of the best costumes in JFC 2016 
The best thing in JFC is the process of creation itself. Participants are volunteers who are recruited through the audition process from various circles, be they employees, students or school children. For about six months, selected participants will receive free training; knowledge of materials; sewing technique; catwalk; performance art; and other relevant training. Participants who have particular skills are required to create their own costumes in accordance with their own creativity with their own cost and energy. They are not allowed to use costumes made by others; each costume is purely the work of the participants, but they will gain in terms of experience, skills, and even economics. Some of the costumes of participants have been hired for various out-of-town events and that is a boon for costume owners.

The success of JFC became a tourism icon with Jember able to deliver 300,000 local and international tourists at the time of the event. In addition, a higher achievement is that JFC helps shape the Jember brand image to the national and even the international stage as a carnival city.

In terms of revenue for Jember City, JFC, which peaks only on one day in a year, is not too big when compared with the entire revenue of Jember. However, JFC is an activator of similar annual activities in the city. In addition, JFC became the cultural icon and identity of the District and City of Jember. With the JFC and other follow-up activities hotel occupancy can increase by $300 \%$ compared to other times, and the number of local and national tourist visitors who do not stay in Jember is certainly much more. In addition, the hotel raises 3fold stay 3 times during JFC. When compared with the length of stay of tourists during JFC, at least they stay an average of four nights, multiplying the revenue for the managers of the JFC dive hotels.

The existence of JFC as icon of Jember, makes Jember a national and international tourist destination on a par with Bali and Yogyakarta. This condition provides an opportunity for stakeholders in the field of tourism to conduct promotional activities and improve their services to welcome the arrival of tourists. When tourists visit JFC of course in the time available both before the event and after the event, they will visit the tourist resorts and other tourist attractions in Jember such as Agro Coffee and Cocoa Science Techno Park tours which experienced a surge of tourists during the JFC event. This tour resort presents the coffee and chocolate industry and the process systems involved to tourists, ranging from visits to coffee and cocoa plantations, using special vehicles guided by local officers, explaining the processing of coffee and cocoa beans from upstream to downstream at existing factories, up until the actual packing of ready-made coffee and chocolate and serving drinks and food made from coffee and chocolate in a convenient place at the resort.

Similarly, the agro-tourism BIN on the outskirts of Jember City, is also busy serving the overflow of tourists who visit during JFC activities. BIN is a cigar manufacturer, exporting especially to Malaysia and on order to other countries. The company offers tobacco agro-tourism to visitors in the form of tours of the tobacco plantations, warehouses and tobacco factories, processing export-quality cigars, with presentations and film screenings regarding tobacco-related issues along with snack, and lunch presentation on request.

In addition to the two tourist resorts that experience a positive effect from the JFC event, there are many other resorts that get an overflow of tourists to achieve three to four times normal weekday occupancy. Surely this has a positive effect also for related small industries, restaurants, transportation services, foodstuffs suppliers, and so forth. This proves that JFC is not only a tourism icon of Jember, but also a catalyst for the wider Jember community economy.

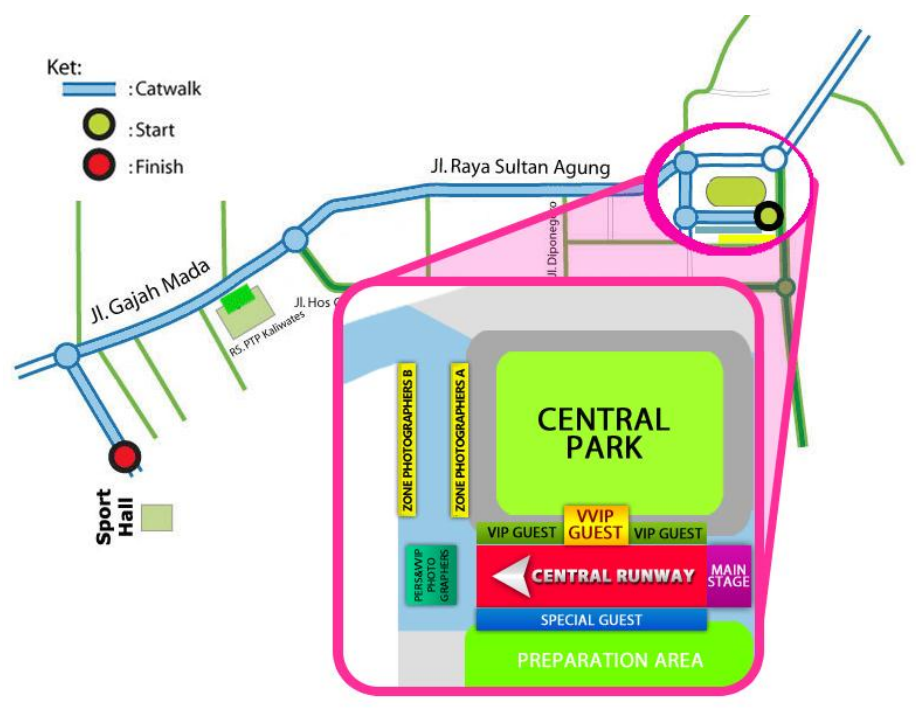

Fig. 5 Route of JFC along this $3.6 \mathrm{~km}$ which initially attracted censure 


\subsubsection{Education}

(1) Through in-house training, the participants are given knowledge of fashion designing, the fashion runway, fashion dance, presentation, and makeup; (2) Through a confident human-born competition, participants can develop into instructors, leaders, choreographers, presenters, singers, entrepreneurs, etc. This is achieved through the discovery of potential participants by providing opportunities for creativity development; (3) Through the competition will be born new ideas in the field of dance, designing clothing, accessories etc.; (4) For the audience it also adds insight into the diverse regional cultures.

\subsubsection{Entertainment}

JFC is an exclusive event that can provide entertainment for the whole community from all walks of life, professions, age, education, economic background and so on.

\subsubsection{Exhibition}

It can become a center of study or research about fashion carnival and a photography subject for professional photographers and many others.

\subsubsection{Economic Benefits}

The organization of events that have a clear concept and quality human resources, are sustainable and interesting, get support from the community, government and people's representatives, allows the event to become a leading tourist attraction that can drive other tourism potential (hotels, restaurants, transportation, souvenirs.)

\subsection{History of JFC}

As mentioned earlier, JFC is an idea developed by Dynan Fariz as a manifestation of his love for fashion and the City of Jember. From the description of JFC manager, the event was first rolled out in 2013 in January. In the same year, they held the same event in August. Until the second show, JFC organizers were Dynan Fariz Carnaval. Beginning the third run, the event was managed by JFCC.

Currently, JFC has entered its fifth year and has been recognized internationally, but initially, JFC received a mixed reception. The scholars criticized the presence of JFC as a Western symbol that could damage local culture, while other artists assumed that JFC does not represent the values of Jember tradition. It also met with refusal from people who did not agree to close the main access road for JFC. It was feared that it would disrupt public order and harm the public. However, after a long and fruitful process, JFC now has the support of almost every layer of society. JFC itself transformed into an integral part of the identity of Jember and began to attend the daily conversation of the community.

\subsection{Between the Government and the Foundation}

Although it has become an icon of Jember City, it can be said that the JFC manager is JFCC. JFCC itself is a non-profit organization whose members is concerned with this event and are thinking about developing a professionally and transparently managed JFC moving forward and audited by authorized institutions.

In funding, JFCC from the start was not profit oriented; it does not receive sponsors who want to get exposure in the implementation of JFC. If there is a sponsor, it must be non-branded. This is done to improve JFC's image through clean photos and footage of videos from corporate logos and other agencies to be published in news agencies around the world. It is recognized by the Department of Tourism and Culture that during this time, JFC is not held without the help of other parties who are fresh money, but this can be in the form of goods or services to assist the implementation.

To support the JFCC's efforts, local governments are involved in the success of JFC primarily through financial support. The district government currently allocates a five billion grant for JFC implementation. Governments and related agencies also do not interfere with creative processes and only play a role in overseeing budget accountability reports. In addition, through the Office of Tourism and Culture, local government also helped register JFC patents on behalf of Dynand Fariz. So, although managed by the pri- 
vate sector, the local government also plays a big role in realizing the biggest performances in Jember, even Indonesia.

JFC has a great impact for Jember, but in its management there are often tensions between Jember Tourism and Culture Office, Regent and JFCC. This is especially true when power changes in the regions. Each era has its own policy in viewing JFC in Jember. This is one of the challenges in organizing events that have brought the name of Jember to the world stage.

JFC has become the most important part of tourism in Jember. The JFC calendar is a reference point for the holding of other events in Jember. A year before the show, JFCC will set the next JFC date, after which the new services adjust their respective events, especially within the tourism agenda.

\section{JFC as Invention of Tradition}

JFC is the work of a creator who has the expertise and personality, who is very determined to realize his ideas to produce something that was not there into reality and accepted by the citizens of the community to develop into an international event. Although the events are something new and deliberately created, the material comes from local traditions and has existed before as part of past lives. The creator in this case, Dynand Fariz, creates local potency consisting of carnival, dance, costume, artists and traditional forms, turned into new cultural events and performed repeatedly every year until accepted by local people before evolving into an international event. Acceptance of the event by the surrounding community, in addition to the material derived from old traditions, is also not contrary to the norms of local communities that apply today.

The various social activities deliberately recreated as described by Hobsbawm (1992) are termed the invention of tradition, a set of fair practices, in accordance with generally accepted rules or norms, through the formation, and planting of values, norms in certain behaviors that take place through repetitions related to past history. The process of the invention of tradition is a process of formalization and ritualization whose characteristics refer to the past and re-enacted repetitively (repetition). This process takes place continuously and is growing widely. The invention of tradition also responds to new situations, although brought from the old situation referenced through the process of repetition (Hobsbawm, 1992). Various traditional invasions that take place in Indonesia such as those that take place at KasepuhanGunungHalimun in Sukabumu; SaungAngklungMangUjo in Bandung and JEC in Jember City, implemented by a creator with a clear goal that is the revitalization of tourism activities in the area that aims to move the economy of society via the multiplier effect.

The existence of JFC young generation (high school students) drives the urge to compete to preserve, love and promote the cultural wealth of the region. In addition, the flow of tourist visits, nationally and from abroad, increased markedly, marked by increasing hotel occupancy rate up to 300\%; a significant increase in the number of tourist visits to resorts in Jember and surrounding areas; revenue from the organizers with ticket costs of IDR 500,000 to IDR.2000,000, with a total of 300,000 visitors; and other parties who benefit from this activity such as supervisors of food and beverage services, local guide services, transportation services, and others.

Creators, in addition to profiting economically, also get other benefits such as influence, ease from the ruler; and various opportunities that can be exploited to develop their creativity. Local governments also benefit economically from the taxes from the various stakeholders involved and regional economic activities that participate in moves that also provide a large enough tax. When these organized cultural events take place three times within a year, it can be imagined that the economic growth in the city will grow rapidly.

\section{Conclusion}

From the above explanation, JFC is a new form of culture that is created by professional figures, supported by various circles so that it can take place repeatedly and develop into a new culture that has a positive effect on the development of tourism and the existence of Jember itself in accordance with its creator's expectations. The JFC phenomenon in accordance with what is called by Hobsbawm (1992) the invention of tradition that is, fair practices that can be accepted by the surrounding community and in accordance with the rules or norms prevailing in the community, rooted in existing culture and these events, through repetition, become a new tradition. In accordance with the properties of the traditional invention attached to JFC it can be concluded:

(1) JFC gets public support because its creators are packing the event because of the culture and traditions that already exist in the local community. 
(2) The support of various groups such as artists, the general public, students, and local government makes the events flourish.

(3) JFC makes Jember better known nationally and internationally in accordance with the expectations of the creators and their supporting community.

(4) Jember tourism boosts the local economy, increasing the popularity, and creativity of artists in accordance with the JFC creator's expectations.

In accordance with the description, it is appropriate that JFC is an invention of tradition that offers many positive effects to society, especially for the tourism industry.

\section{Acknowledgments}

This research was financially supported by PITTA grant Universitas Indonesia.

\section{References}

Cancel, R. (2006). Asserting/Inventing Traditions on the Luapula. African arts, 39(3), 12.

Cannadine, D.(1992) The Context, Performance and Meaning of Ritual: The British Monarchy and the Invention of Tradition, 1820-1977. In Hobsbawm E. \& T. Ranger (Eds.) The Invention of Tradition.Cambridge: Cambridge University Press.

Gunawijaya, J. (2011). Tatali Paranti Karuhun: Invensi Tradisi Komunitas Kasepuhan Gunung Halimun di Sukabumi, Jawa Barat. Disertasi Doktor Tidak Diterbitkan. Depok: Jurusan Antropologi FISIP UI [Universitas Indonesia].

Hobsbawm, E. (1992). Mass-producing traditions: Europe, 1870-1914. The invention of tradition, 263-307.

Hobsbawm, E., \& Ranger, T. (Eds.). (1992). The invention of tradition. Cambridge University Press.

https://jemberkab.go.id/selayang-pandang/

https://jembertourism.com

https://wolipop.detik.com

KabupatenJemberDalam Angka2016

Musthofa, B. M. (2019). PENGEMBANGAN BUDAYA MENUJU KESEJAHTERAAN BUDAYA: Pelajaran Dari Pengembangan Masyarakat Di Saung Angklung Udjo, Bandung, Jawa Barat. Sosio Informa, 4(3).

Ranger, T. (1997). The invention of tradition in colonial Africa. Perspectives on Africa: A reader in culture, history, and representation, 597-612.

Rodríguez, S. (1997). The Taos fiesta: Invented tradition and the infrapolitics of symbolic reclamation. Journal of the Southwest, 33-57.

Shahab, Y. Z. (2004). Identitas dan otoritas: rekonstruksi tradisi Betawi. Laboratorium Antropologi, FISIP UI.

Statistik Daerah KabupatenJember 2016

Trevor-Roper, H., Morgan, P., \& Cannadine, D. (2015). The Invention of Tradition (p. 15). Cambridge University Press. 